\title{
The Role of Incumbent Actors in Sustainability Transitions: A Case of LITHUANIA
}

\author{
Joana Ramanauskaitė (D)
}

Citation: Ramanauskaitė, J. The Role of Incumbent Actors in Sustainability Transitions: A Case of LITHUANIA. Sustainability 2021, 13, 12877. https://doi.org/10.3390/ su132212877

Academic Editor: Prescott C. Ensign

Received: 19 October 2021

Accepted: 18 November 2021

Published: 21 November 2021

Publisher's Note: MDPI stays neutral with regard to jurisdictional claims in published maps and institutional affiliations.

Copyright: (C) 2021 by the author. Licensee MDPI, Basel, Switzerland. This article is an open access article distributed under the terms and conditions of the Creative Commons Attribution (CC BY) license (https:/ / creativecommons.org/licenses/by/ $4.0 /)$.
School of Economics and Business, Kaunas University of Technology, LT-44249 Kaunas, Lithuania; joana.ramanauskaite@ktu.edu; Tel.: +370-630-83-955

\begin{abstract}
To explore what roles incumbent actors take in sustainability transitions, this paper investigates the current situation in the scientific literature, which reveals a shift from opponents to promoters and the case of a post-Soviet transitioning economy that is exemplified by examining five sustainability-oriented incumbent actors in Lithuania. A single case study design is selected as a methodological approach, illustrated by empirical data from interviews and secondary sources (corporate websites and sustainability reports). These examples provide insights on the initiatives the organisations that are already interested in sustainability take to promote sustainability ideas and be active members of the transition themselves, supporting the contemporary view of incumbents as agents of sustainable transitions.
\end{abstract}

Keywords: incumbents; sustainability transitions; sustainability; transitioning economy; case of Lithuania

\section{Introduction}

The role of business and organisations in sustainability transitions is receiving increased attention from scholars in the field [1]. Sustainability transition could be explained by examples in the current trends for the promotion of high value-added sustainable products, alternative and renewable energy sources, and circular or bio-economies [2-4]. The European Union (EU) recognises the importance of sustainability issues and includes them in its policy agenda aimed at building a knowledge-based bio-economy [3,5]. Sustainability transitions refer to purposeful, long-term, multidimensional, fundamental transformations of socio-technical systems towards more sustainable modes of production and consumption, requiring participation of different types of actors [6-8] and therefore, certain structures of analysis. Multi-level perspective (MLP) could theoretically be one of the main mechanisms to explain these processes $[2,6,9]$.

To understand the sustainability transitions, a holistic picture is necessary. The MLP framework provides a deconstruction of sustainability transitions into three levels: niche, regime, and landscape $[3,10,11]$, although it is sometimes considered too simple, relatively straightforward, and unable to capture the inherent complexity of the system change [12-14]. It is interesting and complementing to look at the organisational level of the MLP, best described by the regime level. A regime can be defined as a group of actors sharing a set of rules that are unique to that regime. Interconnectedness and partial overlapping of different regimes guiding actors in a socio-technical system is referred to as the socio-technical regime [2]. There are different actors at play when transitioning towards sustainability, because sustainable development does not address the needs of an exclusive group, but rather incorporates the interests of multiple groups of social actors and even of different generations [15]. Organisations are an important part of sustainability transitions, transforming societies and markets; therefore, the business role in this transition is an important aspect to be explored, complementing the outlook regarding the type and size of the organisations [16-18]. Socio-technical regimes that have been long established may include large, influential organisations at play. These established prominent actors with a 
lifelong history are large both in terms of personnel and revenue, have political power, but are often black-boxed and labelled as homogeneous industry structures with predefined roles and relations, referred to as "incumbent" in the scientific literature $[19,20]$. Interestingly, incumbent actors, even big players in industry and overall country or regional development, were overlooked until quite recently (i.e., [4,20-22]) and are being started to be investigated by researchers of sustainability transitions.

The role of incumbent actors is still being discussed; it is beneficial to look not only at the developed countries, but also see how these possible game changers might affect the developing economies or economies-in-transition. It is noted that the current literature lacks insights from a geographical perspective in the overall context [23]. Research from Eastern European post-Soviet countries is left at the border of peer-reviewed scientific journals, with probable lower acceptance rates of submissions [24]. However, the context of post-Soviet countries is an interesting area for sustainability transition research, mainly because of the recent and ongoing transition from a socialist planned to capitalist market economy $[25,26]$. There was a shift not only in economical arrangements, but also in social and psychological attributes. The past is not easily forgotten, and some of the inhabitants of post-Soviet countries may feel reluctant to engage in sustainability due to the similarity between the communist and sustainability ideas, i.e., shared goods, renting instead of buying; even some nomenclature might resemble the days under the "regime" (i.e., corporate "social" responsibility, "socioeconomic", etc.). However, this paper is not aimed at studying the psychology behind the willingness to participate in the sustainability movement. These remarks on the possible hesitation of post-Soviet communities to address the sustainability issues might be among the reasons why this context is interesting and should be addressed as part of a worldwide research concern.

It is important to study how businesses contribute to sustainable development. This paper relates to Targets 8.3, 12.6, and 12.8 of the Sustainable Development Goals (SDGs) encouraging enterprises, especially influential ones, such as incumbent actors, to actively promote sustainable development, build awareness, and participate in policy and decisionmaking, creating a more sustainable environment [1]. This paper looks at how incumbent organisations promote sustainable development, encourage their stakeholders to be more sustainability-oriented, and how they act themselves, thus accelerating the progress towards SDGs in the wake of the crises of the modern world [1].

This paper takes an inductive research approach. The idea for this paper came while investigating contradictions and tensions in corporate sustainability transitions, which revealed some interesting examples of incumbent actors in the transitioning economy of Lithuania. As a member of the European Union and one of the post-Soviet countries, Lithuania might expose some insights on sustainability transitions and the role of incumbent actors in them. This paper is structured as follows. Firstly, the theory is presented for perceptions on incumbent actors in sustainability transitions and the context of post-Soviet transitioning economy. Secondly, the methodology and a sample of incumbent actors in the context are described. Following this, the research results are presented. Lastly, conclusions and discussions are drawn from the observations in the paper.

The research objective of this paper is to explore the initiatives of incumbent actors in sustainability transitions in a transitioning economy. The research question is formulated as follows: how do the incumbent actors in transitioning economy contribute to sustainability transitions?

\section{Theoretical Background}

\subsection{Role of Incumbent Actors in Sustainability Transitions}

As mentioned previously and agreed upon by sustainability transition researchers, the role of incumbent actors in sustainability transitions is underexplored and is a topic for future research. As was discovered during the scientific literature review, several studies explored the definition of an incumbent actor in sustainability transitions. Their definitions are provided in Table 1 below. 
Table 1. Definitions of incumbent actor in the scientific literature on sustainability transitions.

\begin{tabular}{|c|c|c|}
\hline Source & Definition & Keywords \\
\hline Apajalahti [19] & $\begin{array}{l}\text { "By 'incumbent' most of the studies I have come } \\
\text { across specify this to be an organisation or an actor } \\
\text { with a longstanding history; it is large in size, both in } \\
\text { terms of personnel and revenue; in most cases it is a } \\
\text { well-known firm; and it has political and economic } \\
\text { power (there are also other actors, such as industry } \\
\text { associations, that hold power in the sense that they } \\
\text { represent the majority of an industry)." (pp. 31-32) }\end{array}$ & $\begin{array}{l}\text { Longstanding history } \\
\text { Large size } \\
\text { High income } \\
\text { Well-known } \\
\text { Power }\end{array}$ \\
\hline Borghei [20] & $\begin{array}{l}\text { "However, studies in this field have largely } \\
\text { neglected established actors (i.e., incumbents) and } \\
\text { their potential role(s) in facilitating societal } \\
\text { transformations. Incumbents are black-boxed as a } \\
\text { homogenous set of actors with a pre-defined role in } \\
\text { relation to the established industry structures (Geels, } \\
\text { 2002; Holtz et al., 2008)." (p. 4, citing [11,27]) }\end{array}$ & $\begin{array}{l}\text { Established } \\
\text { Potentially powerful } \\
\text { Homogenous } \\
\text { Inveterate }\end{array}$ \\
\hline Sovacool et al. [28] & $\begin{array}{l}\text { "Drawing from Johnstone et al. }\langle\ldots\rangle \text {, we define } \\
\text { incumbent actors or institutions as those "that often } \\
\text { have vested interests in maintaining the status quo } \\
\text { rather than enabling transitions and will often act to } \\
\text { strategically protect their privileged position" within } \\
\text { a given socio-technological regime." (p. 3, citing [29]) }\end{array}$ & $\begin{array}{l}\text { Status-quo } \\
\text { Privileged } \\
\text { Protective }\end{array}$ \\
\hline Hengelaar [30] & $\begin{array}{l}\text { "Innovation literature commonly defines } \\
\text { incumbents based on their established nature: "firms } \\
\text { that manufactured and sold products belonging to } \\
\text { the product generation that preceded the radical } \\
\text { product innovation" (Chandy, Tellis 2000, } \\
\text { Henderson 1993, Mitchell 1991, Mitchell, Singh } \\
\text { 1993)." (p. 18, citing [31-34]) }\end{array}$ & $\begin{array}{c}\text { Pre-radical innovation products } \\
\text { Manufacturers }\end{array}$ \\
\hline Kungl [35] & $\begin{array}{l}\text { "Incumbents "are those actors who wield } \\
\text { disproportionate influence within a field and whose } \\
\text { interests and views tend to be heavily reflected in } \\
\text { the dominant organization of the strategic action } \\
\text { field" ([4]: p. 13)." (p. 14, citing [36]) }\end{array}$ & $\begin{array}{l}\text { Disproportionate influence } \\
\text { Dominance } \\
\text { Strategic field } \\
\text { Field-bound }\end{array}$ \\
\hline Smink, Hekkert and Negro [37] & $\begin{array}{l}\text { "[I] ncumbents: the firms that mainly have } \\
\text { competencies related to the current technological } \\
\text { regime, and that (financially) benefit from existing } \\
\text { practices." (p. 87) }\end{array}$ & Inveterate \\
\hline
\end{tabular}

These prominent, powerful organisations have a role in sustainability transitions and general change in local or regional environment development. However, how these actors shape the landscape, regime, or niche is still being debated. Earlier works assign a sort of restraining attributes, seeing incumbent actors as keepers of steady, unmovable regimes to stay the way they are [28]. More current studies note other traits of these prominent organisations, characterising them as promoters, sponsors of sustainable transition, those that can notice the change in the market and the needs of stakeholders and are able to respond to the most current trends and demands. Nevertheless, incumbency can be attributed not only to monopolies of firms or powerful governmental players, but also to varieties of different societal dominions, their levels and degrees (market, state, society, etc.) [38], that are not necessarily associated with large enterprises [17]. Incumbents pose a category of specific interest due to their potential power to steer change and entrusted interest [30]. The extracted keywords in Table 1 complement these notions, where authors mention the status-quo incumbents take [20,28,37], their ability to apply power [19,20,35]; however, the size or type of the organisation is not mentioned as often $[19,30]$. Research by van Mossel et al. [2] provided a categorisation of incumbents by their behaviour during 
transition: first to enter, follow into, remain inert, and delay the transition; also supported by other authors [3]. The exploration of the role of incumbent actors as perceived by scientific studies is described in the following paragraphs.

Van Mossel et al. [2] studied the behaviour of incumbent firms during transitions. They began with the notion that incumbents were mostly perceived as locked in their behavioural patterns and reacted passively to the social environment changes. Agreeing with this notion, Hörisch [39], Lindberg, Markard, and Andersen [40], Schaltegger et al. [17], and Turnheim and Sovacool [38] pointed out that incumbents were more likely to invest into economically sound innovations at the niche level, but not radical innovations that disrupt the regime, which the incumbents were more likely to preserve. The size of the company and bureaucratic inertia were among the reasons preventing investment in emerging innovations [4] and stalling sustainability transitions [2]. Sometimes incumbent actors show signs of persistent resistance to or slowing down of the transition because their business models are challenged, and their capabilities and resources are at risk $[35,37,40,41]$, additionally blocking grassroot initiatives [3]. Therefore, a frequent hypothesis is that radical innovations are more likely to emerge from new entrants or smaller enterprises than incumbent actors [28], who commit to existing socio-technical regimes and oppose sustainability transitions [42] directing their resources accordingly.

The incumbent actors have access to excessive resources and might distribute them accordingly to their advantage. These resources (money, capabilities, competencies, influence) are built around the existing processes and routines, resulting in a lack of interest to invest in emerging technologies and breakthroughs that could disrupt the current status of incumbent organisations $[4,38]$. Changing the direction of resource investment would also require changes in the business model, viewed by the incumbent actors with reluctance due to the profitable core activities of economies of scale [4] and the current reputational status. Noticeably, incumbents are not expected to deploy their resources for social collective prosperity and distributional fairness [38]. Large incumbent firms are immersed in multiple regimes, which are also often incumbent, and the resources might be suspended there [2]. Therefore, resources of large incumbents might be a source of power that might be used for various reasons, not only tilting the areas that sustainability transitions struggle in [38], but also to assert the advantage politically.

Although incumbents respond to transitions, the response is not necessarily beneficial for further successful transition [2]; therefore, it is important to understand how incumbents shape their environment [40]. One of the ways incumbents can influence the sustainability transitions is to gain access to policymaking. Some sectors, i.e., energy and agriculture, are particularly politically powerful and might successfully resist fundamental change [42-44]. Possibilities for the incumbents to resist transitions might emerge in forming political coalitions, networks, or alliances [2,43]. By doing so, incumbents can strategically set technical standards and shape expectations and visions for stricter regulations [37], alter and manipulate information and knowledge [38,45]. Incumbent actors tend to favour their interest by actively shaping public policies $[40,46]$ that might provide them with competitive advantage [38]. In any case, active response to sustainability transitions does result in changes in the behaviours of incumbent actors. One way is to resist and try to diminish the impact of ongoing change on their daily routines. Another solution would be to alter their own interorganisational habits, transforming their vision, reorienting their pathways, and gaining benefits by destabilising the existing regimes [38,47].

However, the perception of incumbents as resisters to sustainability transitions has been challenged. Although empirical insights on the role incumbent actors take on in sustainability transitions are scarce [39], incumbents are observed to contribute to the destabilisation or fragmentation of the regime $[38,48]$. The Schumpeterian look on incumbents notes that they are known for improving continuously and incrementally, whereas radical change is attributed to small new firms and entrepreneurs [30,49]; incumbents do contribute to developing innovative transitional technologies [50,51]. Newcomers to the sector could be perceived as challenging not only the market share of incumbents, but 
also their business models [41]. Although incumbents more often might be the keepers of existing regimes, some cases show their willingness to cooperate and invest in the strategic reorientation [41,52]. The incumbents collaborate with new entrants (with or without the intermediation), create common value, and enable newcomers, given their remarkable financial, human, and other resources $[38,47,51]$. This could considerably accelerate and direct transitions towards sustainability. Although incumbents are more likely to participate in reconfigurational changes, they might bring up and adopt economically optimal innovations to the regime from the niche level [39]. Precariously, incumbents tend to hold the significant power of what innovations to pick out and institute at the regime level [39]. However, there are studies showing that incumbents use their capabilities to develop several technological alternatives concurrently to change the directions of stable pathways $[20,50]$. Overall, there is contemporary research that shows a significant contribution of incumbents to sustainable transitions as proponents and promoters of new technologies and change $[39,50,53]$.

Irrespective of the way the incumbents choose to participate in sustainability transitions, there are reasons behind those decisions. As analysed earlier, there are different behavioural patterns the incumbents might display. As the majority of the scientific literature suggests, incumbent actors show a tendency to be hesitant in taking an active role in developing radical innovations and technologies [54]. However, there are internal and external barriers or restraints for incumbents to participate in sustainability transitions. Common external impediments include weak institutions that lack directionality in shaping the transitional context, verbalisation of user preferences, straightforward policies, and regulations [28]. The interorganisational barriers are somewhat harder to define and require a more thorough consideration. Managers of incumbent firms may fail to adequately recognise disruptive threats [28] due to resistance to experimentation and transformation of their stable business processes and models [13]. Lack of knowledge of innovative products required by the market [4] might be at the core behind the fear of change. Established networks that support stable routines of organisations are often supported by technologies and developed competences that are threatened by the emerging new and radical innovations threatening to destabilise the current position of incumbents $[20,28,54,55]$. This notwithstanding, some of the incumbents with active resistance strategies focusing on niche innovations might sustain the carrying out of business as usual [56] for a while, but eventually, locking themselves into routines, technical capabilities and failure to recognise the destabilisation caused by disruptive technologies might result in the downfall of incumbent actors [57].

However, there are stimulating factors, promoting and encouraging incumbents to take an active and positive turn towards sustainability transitions that are being discussed in the current literature. Firstly, there are economic incentives at play that bring attractiveness and financial opportunities to push the transition process towards green niche innovations [42], whose policies have become more favourable for incumbents in the past few years, easing the transition [57]. Experimenting with new technological paradigms and niches provides impetus to overcome both internal and external barriers and allows to adapt to new markets faster, exploiting their current knowledge base and developing new competencies $[4,17]$ and increasing their chances of survival, even though an incumbent might become dependent on the fate of the niche [2]. Introducing incumbents to sustainability ideas and societal missions might become important pushing these ideas into political level decision-making, simultaneously making the transition less disruptive, therefore, more attractive [28,40]. Moreover, incumbents with diverse capabilities and resource bases are more likely to survive in unstable environments [2]. Nonetheless, when faced with external pressure of new more sustainable entrants to the market, incumbents might engage in sustainability in their own way, achieving broader impact with the scale of the market they already share [22].

An outside stakeholder could bring a better vision and understanding of the current situation and of the benefits it could bring to the organisations. These external interested 
parties are "transition intermediaries-agents who connect diverse groups of actors involved in transitions processes and their skills, resources and expectation" [28] (p. 1). Sovacool et al. [28] dedicated a research to incumbent-oriented transition intermediaries and noted that this field was getting more prominent. Transition agents bring an upheaval and disruption to the regime, maintaining contact with stakeholders that have different interests in the transition. By becoming involved into these established ecosystems, transition intermediaries might cause conflict with incumbent business alliances [28,41]. The intermediaries are known for their push of new innovations from the niche level to regimes and protecting them from being overwhelmed by the resisting incumbents. This also requires intervention into policymaking. Providing acceptable prospects for both newcomers and incumbents, transition intermediaries might create win-win situations for the stakeholders, adding a third win for the sustainability transitions as a public good by using their abilities in either helping mobilise the resources, consulting on technology use, linking actors with similar interests and complementing resources, pushing environmental innovations and enabling the growth of niches, or lobbying at the political level [58]. Enabling new technologies offers a renewal for success that could be used for benchmarking by the incumbents and their regimes [41]. Collaboration is nonetheless key for enabling incumbents to invest in sustainability transitions.

Given the resources and capabilities that incumbents possess, they could be the accelerators of sustainability transitions if they recognised the necessity to reconfigure and transform $[22,28,42,51]$. Nevertheless, incumbents could serve as hybrid actors, linking niche innovations to incumbencies and thus altering and disrupting the regime [47], by taking part in the activities both in or between the regime and niche levels, bringing a new set of rules and requirements, even when operating in their own interest, with creation of links being their secondary concern [59], supporting the stable socio-technical system with constant fluctuation, never reaching a firm balance [2]. Hybrid organisations also possess the ability to gain profit not only with the quality of their services and products, but also to contribute to positive environmental and social change with their mission, with the profit not being the main objective, blurring the borders between for-profit and non-profit organisations [60], creating added value both to business and society [16]. This becomes achievable because hybrid organisations collaborating with the stakeholders of their social context strive to solve environmental and social issues through their practices and products, rather than just trying to reduce their negative impact $[16,60]$. Even when starting with incremental improvements, incumbents could create radical innovations, impacting the market when accelerated, and being adapted throughout the regime and niches [17]. Nonetheless, it is also necessary to keep in mind that these socio-technical systems are context-dependent and their individual transitions may vary depending on different circumstances [40].

Incumbents, being prominent actors in their sectors and regions, that can attribute their resources to influencing other members of the landscape developments, may take various roles in sustainable transitions, ranging from inhibitors to promoters and leaders:

- Resourceful opposers of sustainability transitions $[4,42,56]$;

- Politically powerful environment shapers [40,42,44];

- Knowledge manipulators [38,45];

- Keepers of existing regimes $[41,52]$;

- Incremental innovators [30,39,49-51];

- Promoters of new technologies and change [39,50,53];

- Hybrid actors [47,59].

Moreover, as some of the scientific literature on incumbent actors' role in the scientific literature on sustainability transitions mention the size and type of the firm (large manufacturers), these attributes are not necessarily important to address when looking at incumbent organisations. Incumbency of the organisation relies more on their strategical stance in the market, where they are established, prominent, with a set of network connections and stable positions that are not easily moved [61] by shifts during the development and pertur- 
bances of the landscape or the regime, allowing them to take any of the abovementioned roles.

\subsection{Specificity of the Context of Transitioning Economy of a Post-Soviet Country}

Lithuania is a country situated on the south-eastern side of the Baltic Sea with only 30 years of independence from the Soviet Union regime that has been shaping the country for 46 years. Lithuania is in a geopolitically active area with transit roads and most northern ice-free port of the Baltic Sea, which places the country in a position to successfully develop its economy. Currently, Lithuania belongs to the EU and NATO, providing both incentives and safety for successful independent development $[25,62]$. Sustainable development was started to be addressed in the early 2000s by being included into the National Strategy for Sustainable Development [63] and being recognised by companies creating Lithuanian Responsible Business Association (LAVA_Lietuvos Atsakingo Verslo Asociacija) in 2005, extending the work of the National Network of Responsible Business Enterprises (NAVITNacionalinis Atsakingo Verslo Imoniu Tinklas). Generally, the direction of companies represents the interests of consumers, shareholders, and other stakeholders, such as governments, policymakers, general society, etc. There are studies that investigate transitions of companies from planned to free market in the post-Soviet bloc [25,64], but not so much regarding sustainable development of the enterprises or countries. Search on the Web of Science Core Collection did not provide any results for keywords post-Soviet, sustainability transitions, organisation/business, and their synonyms. This might be due to the difference between sustainability and market transition, where sustainability is regarded as socio-technical, and market as a socio-economic system [25]. This notwithstanding, these systems are highly interlinked and co-dependent.

The Soviet Union did leave an imprint that might be felt in the contemporary society of the affected countries. The cultural legacy of this regime had multiple indirect negative impacts [23,65] in a broad variety of areas. Dawson [65] named several attributes linked with the mentality of post-Soviet countries: "passivity, circumspection, distrust, and a widespread indifference to environmental issues, pervading society, including governance systems, at multiple levels" (p. 56). Therefore, instead of gradual transition from one regime to another, these countries experienced shock-therapy $[25,26]$ and some authors in the geography field refer to this transition more of as 'a form of transformation' $[26,66,67]$. However, experiencing these transitions, or transformations, possibly prepared the countries for sustainable transitions. Rodrigo et al. [23] conducted a study on transition dynamics and through comparison distinguished four groups of countries in terms of the way they approach sustainability issues: crossroaders, compliers, athletes, and laggards. The cluster of compliers contains fifteen ex-eastern bloc nations (except for Uzbekistan) that do particularly well in the quality of governance, but not in creating wealth cleanly, though they try to follow more sustainable paths, having not been exposed so much to the sustainable development concept. Growing economically strong, the compliers' cluster is not noted for effective and efficient energy management; however, they are addressing their effect on socio-environmental conditions, trying to improve it and comply with the standards raised by alliances such as the EU. Complier countries in the EU or those in the process of becoming a member must fulfil higher standards; however, they are not addressing their energy and $\mathrm{CO}_{2}$ emission issues appropriately yet. Lithuania is presented as one of the exemplar cases complying with sustainability requirements through the use of some governmental pressures; it adopts improved industrial practices, takes moderate steps to reduce poverty and $\mathrm{CO}_{2}$ emissions, but uses energy quite inefficiently, however, trying to develop more sustainably [23]. Citizens of the eastern post-Soviet bloc share the commonalities of inadequate energy use and a large proportion of the population is shown to struggle heating their houses in the cold periods and are experiencing energy poverty [68]; furthermore, are also undecided about the climate change [69].

Some challenges particular to Lithuania include limited availability of public transport; $10.6 \%$ of the population do not have access to indoor sanitation; the income of $20 \%$ of the 
richest people in the country was 7.1 times higher than $20 \%$ of the poorest people [70]; 20th place in the SDG Index of 2018 among 27 EU countries. Sustainable development principles in Lithuania are established through the main strategic planning documents of the country: Lithuania's Progress Strategy “Lithuania 2030"; 2014-2020 National Progress Programme; National Strategy for Sustainable Development adopted in 2003; the White Paper on Lithuanian Regional Policy prepared in 2017. The necessity for sustainable development is also mentioned in the Law on Territorial Planning of the Republic of Lithuania. However, it is noted that the topic of sustainable development lacks coherence and specificity in these documents, while the key issue in this regard is strategy: the National Strategy for Sustainable Development is more of a recommendatory nature [70]. Correspondingly, the Lithuanian National Sustainable Development Strategy has not been updated since 2011, whereas its implementation reports have not been submitted since 2014.

Nevertheless, membership in the EU had a major impact on Lithuania's development patterns. Post-Soviet countries that are members of the EU established market economy faster and performed wider-ranged reforms [62]. Integration in the EU can be seen as a stimulus for improving governance, having examples set by older members and absorbing sustainable development goals as part of the strategy [71]. Following the lead of more prominent EU countries that already have transitional experiences and competencies, should provide these transitioning economies with a boost for integrating sustainable development principles in their routines. The similarities between socio-technical and socio-economical system transformations should help transfer the multilevel concept of sustainable development to the market transition [25]. However, as the analysis above suggests, it is not to be expected from an incumbent regime to actively engage and invest in radical innovations as top-down initiatives do not intentionally generate niches and evolutionary bottom-up processes [18]. Therefore, it is important to address the initiative grounds of sustainability transitions, which could lay in incumbent actors in the context.

\section{Materials and Methods}

As a methodological approach, a single case study was selected to explore the incumbent actors' role in sustainability transitions in Lithuania. The majority of sustainability transitions' literature on incumbent actors is focused on energy sector. This landscape of Lithuania also has one of the main incumbent actors operating in energy sector. Therefore, information and examples of other incumbent actors will be drawn to better illustrate how companies in an emerging economy take the initiative and promote sustainable development. Five sustainability-oriented incumbent organisations in Lithuania were selected using nonprobability purposive sampling. First selection criterion was that the organisation had to be a part of the UN Global Compact initiative or a member of LAVA. The interviewed organisations could be categorised as incumbent actors in their sectors in Lithuania, being prominent and influential actors of their fields and active members of society, visible to the broader public, as a second criterion, where only two are large and have annual income above $€ 100$ million. After the second criterion was applied, an organisation that is not a part of UN Global Compact initiative or a member of LAVA emerged. Since it manages a national environmental brand label, it was included into the sample. Homogeneity of the sample is assured following the definition of incumbents that agrees with the research of Borghei [20], Sovacool et al. [28], Kungl [35], and Smink et al. [37], describing incumbents as established, prominent, and influential organisations. Characteristics of the interviewed organisations are provided in Table 2. 
Table 2. Characteristics of respondents.

\begin{tabular}{|c|c|c|c|c|c|c|c|}
\hline Organi-Sation & Sector & Size & $\begin{array}{c}\text { Income, Mill } € \\
\text { (2019) }\end{array}$ & Years Active & $\begin{array}{c}\text { UN Global } \\
\text { Compact }\end{array}$ & LAVA & Respondent \\
\hline OrgC & $\begin{array}{l}\text { Support } \\
\text { services }\end{array}$ & Very small & $0.3-0.5$ & 18 & + & - & Director \\
\hline OrgD & Academic & Large & $8-11$ & 21 & + & - & $\begin{array}{l}\text { Sustainability } \\
\text { coordinator }\end{array}$ \\
\hline OrgE & $\begin{array}{l}\text { Gas, water and } \\
\text { multiutilities }\end{array}$ & Large & $>100$ & $\begin{array}{c}12 \\
(84)\end{array}$ & + & + & $\begin{array}{l}\text { Communication } \\
\text { manager for } \\
\text { sustainable } \\
\text { development }\end{array}$ \\
\hline OrgM & $\begin{array}{l}\text { Support } \\
\text { services }\end{array}$ & Small & $1-3$ & 17 & - & - & $\begin{array}{c}\text { Environment } \\
\text { and } \\
\text { sustainable } \\
\text { development } \\
\text { policy } \\
\text { specialist }\end{array}$ \\
\hline OrgR & Bank & Large & $>100$ & 27 & + & + & $\begin{array}{l}\text { Sustainability } \\
\text { manager }\end{array}$ \\
\hline
\end{tabular}

Semi-structured interviews were conducted online using video conferencing means in Lithuanian during the period of November 2019 to August 2020. Interview questionnaire was built in consideration of the researches by Van der Byl and Slawinski [72] and McGrail et al. [73], revealing the organisations' stance towards sustainability. Representative questions are provided below:

- Could you tell when and on whose initiative social responsibility or sustainability became part of your organisation's strategy?

- Could you provide examples of social initiatives or solutions that your organisation is implementing?

- Could you provide examples of environmental initiatives or solutions that your organisation is implementing?

- Could you provide examples of economic initiatives or solutions that your organisation is implementing?

- What impact have the stakeholders had on the implementation of the social, environmental, and economic decisions you mentioned?

- What value and why did these social, environmental, and economic decisions bring to your organisation?

Transcripts of the interviews were made adopting a literal transcription strategy. Deductive qualitative coding [74] was applied to the transcripts where the codes (initiator; social, economic, environmental initiatives; stakeholders; value) were developed and complemented with the information from the interviews.

As additional information sources, corporate websites, and sustainability reports (of those organisations who report) where consulted using the same representative questions. This strategy was selected to complement the informants' knowledge with corporate sustainability communication, check for testimonies and validate the information.

\section{Results}

This section is dedicated to exploring the examples of five sustainability-oriented Lithuanian incumbents. Detailed stories and testimonies from the respondents are presented in Tables 3-7, providing information on why organisations took on the sustainability approach, their social, environmental, and economic initiatives, their stance towards stakeholders, and the value they see in being more sustainable. 
Table 3. Testimony from the respondent on the sustainability of OrgD.

\begin{tabular}{|c|c|}
\hline Whose initiative & $\begin{array}{ll}\text { - } & \text { Environmental institute established in } 1991 \\
\text { - } & \text { Coordinated action since } 2010 \\
\text { Green higher education institution initiative started in } 2012\end{array}$ \\
\hline Social initiatives & $\begin{array}{l}-\quad \text { No jeans month } \\
\text { Equal Opportunities Commission } \\
\text { Blood donation campaigns } \\
\text { - } \quad \text { Environment cleaning initiatives } \\
\text { - }\end{array}$ \\
\hline Environmental initiatives & $\begin{array}{l}\text { - } \quad \text { Modernisation of heat and electricity facilities on the campus } \\
\text { - } \quad \text { Seduction in energy usage } \\
\text { - } \quad \text { Development of technologies for disinfection of drinking water, protection against microbes } \\
\text { - Development of an odour-sensitive sensor system that is able to detect air pollution }\end{array}$ \\
\hline Stakeholders & $\begin{array}{l}\text { - Organisation of events and open lectures for the community } \\
\text { Representatives participate in various TV and radio shows, provide press comments on various sustainability issues, } \\
\text { spreading the message }\end{array}$ \\
\hline Value & $\begin{array}{l}\text { - } \quad \text { Prestige, representation to the public } \\
\text { Raising awareness }\end{array}$ \\
\hline
\end{tabular}

Table 4. Testimony from the respondent on the sustainability of OrgM.

\begin{tabular}{|c|c|}
\hline Whose initiative & - While consulting another company for a project, it became clear that we also have to become sustainable \\
\hline Social initiatives & $\begin{array}{l}\text { - } \quad \text { Four-day week } \\
\text { Organising nature festivals } \\
\text { - } \quad \text { Samily is brought to work } \\
\text { - } \quad \text { Blood donation campaigns } \\
\text { - } \quad \text { Shaping the political level } \\
\text { - } \quad \text { Representing environmental interest of the public in court } \\
\text { Defending the public's right to nature }\end{array}$ \\
\hline Environmental initiatives & $\begin{array}{l}\text { - } \quad \text { Renovating the office using green measures, such as adobe floor, or ecological wall paint } \\
\text { - Calculating eco-footprint } \\
\text { - } \quad \text { Corting, weighting their waste } \\
\text { ecologic footprint they leave } \\
\text { - } \quad \text { Sustainable requirements for organised events, such as vegetarian food, eco-certified venues } \\
\text { - } \quad \text { Eurating protected area brand } \\
\text { Encouraging all small producers in protected areas to put on a brand label } \\
\text { Training, teaching small producers marketing, sustainability, and responsibility }\end{array}$ \\
\hline Economic initiatives & $\begin{array}{l}\text { Economic responsibility is understood more as product responsibility } \\
\text { - } \\
\text { Edapting to the economic capacity of partners } \\
\text { - } \\
\text { Quality assurance of services } \\
\text { Principle of fair price } \\
\text { Publicity }\end{array}$ \\
\hline Stakeholders & $\begin{array}{l}\text { - Raising the awareness of politicians } \\
\text { - } \quad \text { Raising the awareness of customers } \\
\text { - The Green Deal affects all activities strongly } \\
\text { - } \quad \text { Other non-governmental environmental organisations are very important as partners } \\
\text { - } \quad \text { Frfluential academic institutions } \\
\text { what is relevant in the market from them }\end{array}$ \\
\hline Value & $\begin{array}{l}\text { - } \quad \text { Retention of valuable professionals } \\
\text { - } \quad \text { Calculating the footprint attracts clientele } \\
\text { Acting according to their words }\end{array}$ \\
\hline
\end{tabular}


Table 5. Testimony from the respondent on the sustainability of OrgC.

- From the parent organisation

- Global Compact pushed to document

Whose initiative - Being open and transparent were the inner values when starting the organisation

- Very protective of staff

- Transparency

- Public education on IT skills

- Educating and training customers, businesses, and government agencies in

Social initiatives the area of social responsibility

- Talking about waste through creativity and art

- Students and community interact with the waste management facility

- Initiative of public emotional security project

- Supplementary health insurance for employees

- $\quad$ Educating public sector on green office solutions

- Educating and organising excursions for schools regarding waste management

Environmental

- Collaborating with the university regarding the training of hazardous waste initiatives managers

- Educating members and employees of governments and municipalities regarding waste management

- Initiating emission transparency in waste management facilities

Economic initiatives

- Training economically active people and retirees to use the internet

- Change in the remuneration of employees in public relations agencies

Stakeholders $\quad$ B Being the initiator of sustainability initiatives

- Avoid spreading disinformation

- Employee loyalty and commitment of employees to adhere to and represent

Value the principles and to adhere to the organisation's philosophy

- Actions are in line with the philosophy, which is value for the clients 
Table 6. Testimony from the respondent on the sustainability of OrgE.

Whose initiative

\section{Environmental initiatives}

- Requirement of the Stock Exchange

- The importance of social responsibility has risen from subsidiaries, making it a part of strategy of the group

- Human rights, zero tolerance for discrimination

- Domestic legislation

- Code of ethics

- Attract more women to technological specialties

- Promoting a culture of safe work

- Internal education campaigns regarding safety at work

- Public education on energy

- Employees tell about efficient energy use to the outside stakeholders

- Maintaining personal contact with communities

- Supporting and meeting environmental management standards

- Promoting energy efficiency

- Helping both the population and business to have a significant impact on the environment

- Producing the majority of energy from renewable sources

- Issuing Green Bonds that are used to finance green energy projects or energy efficiency projects

- Smart energy club

- Developing the network of electric car charging stations

- Joining the United Nations Business Ambition for $1.5^{\circ} \mathrm{C}$

$\begin{aligned} & \text { - Ethics, anti-corruption } \\ & \text { - } \text { Code of ethics } \\ \text { Economic initiatives } & - \text { Annual tests for employees regarding anti-corruption } \\ & - \text { Testing partners' responsibility and sustainability } \\ & \text { - Utility bills can be paid for free by customers using their self-service website } \\ & \text { - Customers experiencing financial difficulties can defer their payments }\end{aligned}$

- Clear requirements from the state

- The highest standards of transparency are required by the shareholders and investors

Stakeholders

- Management standards, benefits maximise employee retention

- The media

- Goal-to get stakeholders a little bit more involved so that they would provide feedback

Value

- Reputation improvement

- Periodic public surveys to evaluate the reputation

- No budget for publicising social responsibility 
Table 7. Testimony from the respondent on the sustainability of OrgR.

\begin{tabular}{|c|c|}
\hline Whose initiative & $\begin{array}{l}\text { - Most strategic, political sustainability issues come from the parent company in Scandinavia } \\
\text { - } \quad \text { Very high level of enthusiasm and support for this topic comes from the CEO of the Lithuanian branch }\end{array}$ \\
\hline Social initiatives & $\begin{array}{ll}\text { - } & \text { Financial education } \\
\text { - } & \text { Promoting entrepreneurship } \\
\text { - } & \text { Increasing awareness of sustainability } \\
\text { - } & \text { Employee volunteering initiative } \\
\text { - } & \text { Equal opportunities and diversity } \\
\text { - } & \text { Finance laboratory human rights conference } \\
\text { - } & \text { A diverse programt communication on personal finance, savings, pensions, investment, macroeconomics } \\
\text { - } & \text { Endorsing and supporting women and entrepreneurs on innovations }\end{array}$ \\
\hline Environmental initiatives & $\begin{array}{ll}\text { - } & \text { Helping customers make more sustainable decisions } \\
\text { - } & \text { Green leasing } \\
\text { - } & \text { Invecial financing services for solar power } \\
\text { - } & \text { Sustainability risks are assessed in the same way as any other }\end{array}$ \\
\hline Economic initiatives & $\begin{array}{l}\text { - } \quad \text { Start-up space for moving to sustainable innovation } \\
\text { - } \quad \text { Small Business Growing Programme } \\
\text { - } \quad \text { Having sustainability criteria in the funding processes }\end{array}$ \\
\hline Stakeholders & $\begin{array}{l}\text { - Change of initiatives' partners is not common } \\
\text { - } \quad \text { Smployees are always important } \\
\text { - } \quad \text { Institutional decision-makers, including the non-governmental sector, other companies with similar values } \\
\text { - } \quad \text { Edith whom we can do some joint activities } \\
\text { - We proceed wission rather than responding to what clients would like } \\
\text { - Internal educational activities about sustainability }\end{array}$ \\
\hline Value & $\begin{array}{l}\text { - You will not be able to do successful business in any society that is doing badly } \\
\text { - If a company is not sustainable, it will be harder to attract the younger generation of employees } \\
\text { - The international investment community has already made it clear that all investments will be directed only } \\
\text { at sustainable businesses } \\
\text { - Failure to comply with legal requirements has the potential might lead to being expelled from the market } \\
\text { Public image }\end{array}$ \\
\hline
\end{tabular}

OrgD is a one of the top state-owned higher education institutions in Lithuania. This organisation presents its sustainability approach on its website; however, the report is outdated. The newest sustainability report can be found on the UN Global Compact website.

OrgM is a non-governmental non-profit organisation that operates in environmental protection area. OrgM reveals its mission on its website and on its sustainability report (as a part of its Activity report). Sustainability-oriented projects, activities, and initiatives can be found in both information sources (Table 4).

OrgC is a public relations organisation with affiliation to a larger company abroad. Double-checking the corporate website and sustainability report, little information could be found. Neither the website, nor the sustainability report mentioned stakeholder testimonies or their impact on the environment. A sustainability report is not on OrgC's website but it can be found on the UN Global Compact webpage (Table 5).

OrgE is a state-owned energy company, the most prominent incumbent in Lithuania's energy sector. The organisation has a very detailed approach to their sustainability strategy both on the website and in the sustainability report (which is a part of the annual financial report provided both on their website and that of the UN Global Compact) Table 6.

OrgR is one of the largest banks in Lithuania based on Scandinavian capital. 
OrgR has sustainability as a part of their strategy, which is visible both on their website and sustainability report (which is provided alongside the Financial report). The report presents their activities, initiatives, and achieved results in great detail. The website shows consistency on all aspects of sustainability as well (Table 7).

\section{Discussion}

Interesting insights that illustrate Lithuania's regime and landscape levels could be drawn from the interviews and secondary data. A similarity shared by these organisations is that their top managers are involved in sustainability transitions and are active promoters of these ideas making them active members of transition towards sustainability both in their activity area and in the broader society. Some of these organisations became involved in sustainable movements around early 2000's participating in the development of the aforementioned association LAVA, making them prominent and long-lasting members of sustainability transitions in Lithuania. Nevertheless, respondents did notice that their clients, general society, and other stakeholders were still somewhat reluctant to address the sustainability issues, thus making it more complicated to initiate change and push these ideas beyond the company borders. Additionally, these organisations also face struggles from within. In example, OrgD encounters problems when broader and larger quantities of resources are required to implement the projects. In essence, looking at the interview data, website, and sustainability report, OrgD appears to have a fragmented approach towards sustainability; though, good intentions. OrgE has an abundance of statistical information on their report; however, some of the declared numbers that might be seen as controversial are not extensively elaborated upon, i.e., employee distribution by gender. OrgR's commitment to sustainable investment seems somewhat vague and unambitious, renouncing financing only to destructive activities, such as guns, coal energy, and those violating human rights.

Respondent from OrgM, who also is an expert in environmental and sustainability issues, noticed a huge difference in terms of corporate social responsibility: big organisations always have documents with clearly defined principles, and small organisations just have sustainability rising from within. Sustainability relates not so much to the organisation, but rather to the people that create the culture within. Those organisations that wanted to start a movement of change towards sustainability began looking for possibilities to collaborate, collect the positive examples from other companies, maybe even benchmark themselves against other sustainability-oriented enterprises, thus creating an informal network of socially responsible businesses in Lithuania (NAVIT) in the beginning of 2000"s. However, OrgC's respondent admits that when looking globally, in addressing sustainability, Lithuania still lags four or five years behind. Therefore, it is necessary to be proactive in discovering sustainability and managing risks in the organisations and other social constructs, to have a steppingstone to move forward and communicate and consult, and include all stakeholders, according to the respondent of OrgM. Though the research may not yet show a strong willingness to pay extra for a sustainability focus in a product or service, that trend is growing, as noted by the respondent of OrgR. Organisations are also more prone not to push sustainable ideas actively to the clients, but to focus on philanthropy and sponsorship as an act of sustainability (respondents of OrgM and OrgC). There are organisations using social events (like marathons) to gather sensitive data on people participating in them and then promoting their products directly (OrgM's respondent). Nonetheless, there are companies that are unequivocally profit oriented and do not have, want to have, or discuss sustainability. The majority of those who address sustainability still see this as a responsibility of the communication department. However, respondent of OrgR notes that unsustainable businesses will not have a place in the future and today, sustainability is becoming a business topic, an important topic. The enthusiasm that is being expressed by the respondents of the analysed organisations could be illustrated by the reflection of OrgM's respondent: "sustainability and social responsibility are not the implementation of some standard, they are not the implementation of some postulates, they are not a policy, 
they are not a principle. It's that jazz that should drive that organisation and should just be fun, becoming a part of that organisation." What seems to be clear from the literature and empirical analysis, is that collaboration between organisations is necessary to tackle the issues of sustainability [16], with key success factors for adapting sustainability at the core of the corporation being structure, culture, leadership, communication, employee qualifications and motivation, and management control [48,75].

Moreover, a trend could be drawn from this small sample of organisations that prominent organisations can dedicate a broad variety of resources to address their corporate sustainability and the message they send, which is visible in their websites and sustainability reports. Naturally, this does not imply that large incumbents are more interested in what message to send than actually living up to the promise. Larger organisations can allocate more resources to various activities, where smaller organisations invest their limited resources to the actual activities. Additionally, large incumbents ascribe greater value to SDGs in their communication sources, structuring their messages accordingly: which SDGs are important to them, to which SDGs do they contribute the most.

This overview on Lithuania's incumbent actors provides insights that support the emerging ideas that incumbents are not only stalling the sustainability transition and anticipating change- they can be active promoters of sustainability ideas who actively motivate their stakeholders to take the sustainability path and try to educate the larger society, taking on initiatives and leading the change, complementing the research of Berggren et al. [50], Hörisch [39], and Markard [53]. Additionally, OrgM reveals traits that are inherent to hybrid actors, linking niche innovations of small enterprises with other market players [47] and maintaining economic profit while adding value to society and the environment $[16,60]$. OrgE provides an example of positive change in the policy of energy sector acting as a politically powerful environment shaper, bringing up the transition from inside and supporting decentralisation and green energy ideas, taking action in building a more sustainable energy supply, whilst other scientific researches provide a more negative depiction of state-owned enterprises $[40,64]$. Moreover, even though incumbents as incremental innovators are often referred via technological solutions, $\mathrm{OrgR}$ poses as an example of incremental developer of society, taking small steps for the education of communities in various directions.

However, the major portion of previous literature on incumbents in sustainability transitions relies on energy sector examples, whereas the sustainability transitions in the post-Soviet context focus on urban/rural development and/or agriculture. Consequently, comparison with other sectors is complicated. Insights on business development and impact on tackling sustainability issues remain an underexplored area both in the case of sustainability transitions and post-Soviet country context. Interestingly, Chatzimentor et al. [24] noted that studies from eastern and post-Soviet countries were often left at the periphery of peer-reviewed journals, having lower-acceptance rates [76,77]. Nonetheless, this research, like the larger part of other transition studies, is designed to be more illustrative and exploratory than a systematic research, possessing elements of interpretation and creativity in its methodology [51]. This paper illustrates how organisations of a transitioning economy take on the initiatives to become more sustainable, empowering their stakeholders to take a part in the transition towards sustainability, when the government still lags behind, trying to meet the requirements set by foreign partners and alliances.

\section{Conclusions}

The aim of the paper was to explore what roles do the incumbent actors take in the sustainability transitions. The scientific literature review suggested seven roles: resourceful opposers of sustainability transitions; politically powerful environment shapers; knowledge manipulators; keepers of existing regimes; incremental innovators; promoters of new technologies and change; hybrid actors. The analysed sample of five sustainability-oriented incumbent organisations in a transitioning economy revealed that they all are promoters of change; additionally, one could act as a hybrid actor; two organisations highlighted positive 
attributes of two roles, one being politically powerful shaper and the other-an incremental innovator. Moreover, the incumbent actors that take on the role of promoting sustainability are emerging in Lithuania and their positive examples supplement the shifting views on incumbents in the scientific literature. This paper, as an overview of the situation in an emerging economy, provides ideas and a steppingstone for future research regarding the role of incumbents that could be used to advance and facilitate the management of sustainability transitions.

Limitations of this paper include a purely qualitative approach when investigating examples of incumbent actors, drawing only from data provided by the organisations: interviews with respondents who themselves were very interested and vested in sustainability ideas and movement, corporate sustainability reports, and websites. One of the ways to further develop this research would be to explore the organisations more thoroughly, looking within these organisations for clues whether there was interest from certain individuals, or all members of organisations supported the sustainability ideas. MLP is better suited for describing events than looking at causal relationships $[14,18]$; therefore, this research, aimed at exploring the role of incumbent actors, is limited at the level of incumbent actors' initiatives, with only slight insights into why they transition towards sustainability and their certain manner, contributing more to a geographical perspective of the sustainable transitions. It could also be interesting to examine whether transition from planned to market economy provided any advantage transitioning towards sustainability. Correspondingly, an investigation of how the post-Soviet country mentality shaped the actions of incumbents could provide fruitful insights into the pathways these organisations are taking and why. Due to early stages of sustainable development idea implementation in strategies in transitioning economies, this might be impossible to assess yet.

Funding: This research received no external funding.

Institutional Review Board Statement: Not applicable.

Informed Consent Statement: Informed consent was obtained from all interviewees involved in the study.

Data Availability Statement: The data presented in this study are available on request from the corresponding author. The data are not publicly available due to privacy restrictions and anonymity of the respondents.

Acknowledgments: I would like to express my gratitude to the communities of the 27th Annual Conference of the International Sustainable Development Research Society (ISDRS) and the 6th NEST conference and the Network for Early career researchers in Sustainability Transitions for the possibility to present my research and receive feedback that allowed me to develop this paper. I would also like to thank the anonymous reviewers who have brought wonderful insights to improve my research.

Conflicts of Interest: The author declares no conflict of interest.

\section{References}

1. Ramanauskaitè, J. Incumbents in sustainability transitions in the context of transitioning economy: An onlook of incumbent actors' initiatives. In Proceedings of the ISDRS 2021: The 27th International Sustainable Development Research Society Conference: Accelerating the Progress towards the 2030 SDGs in Times of Crisis, Östersund, Sweden, 13-15 July 2021; Johansson, C., Mauerhofer, V., Eds.; Mittuniversitetet: Östersund, Sweden, 2021; p. 392.

2. van Mossel, A.; van Rijnsoever, F.J.; Hekkert, M.P. Navigators through the storm: A review of organization theories and the behavior of incumbent firms during transitions. Environ. Innov. Soc. Transit. 2018, 26, 44-63. [CrossRef]

3. Strøm-Andersen, N. Incumbents in the Transition Towards the Bioeconomy: The Role of Dynamic Capabilities and Innovation Strategies. Sustainability 2019, 11, 5044. [CrossRef]

4. Hansen, T.; Coenen, L. Unpacking resource mobilisation by incumbents for biorefineries: The role of micro-level factors for technological innovation system weaknesses. Technol. Anal. Strateg. Manag. 2017, 29, 500-513. [CrossRef]

5. Birch, K.; Levidow, L.; Papaioannou, T. Sustainable Capital? The Neoliberalization of Nature and Knowledge in the European "Knowledge-based Bio-economy." Sustainability 2010, 2, 2898-2918. [CrossRef] 
6. Markard, J.; Raven, R.; Truffer, B. Sustainability transitions: An emerging field of research and its prospects. Res. Policy 2012, 41, 955-967. [CrossRef]

7. Schlaile, M.P.; Urmetzer, S. Transitions to Sustainable Development. In Decent Work and Economic Growth; Leal Filho, W., Azul, A.M., Brandli, L., Özuyar, P.G., Wall, T., Eds.; Springer International Publishing: Cham, Switzerland, 2019; pp. 1-16. ISBN 978-3-319-71058-7.

8. Lyytimäki, J.; Vikström, S.; Furman, E. Voluntary participation for sustainability transition: Experiences from the 'Commitment to Sustainable Development 2050'. Int. J. Sustain. Dev. World Ecol. 2019, 26, 25-36. [CrossRef]

9. Fuenfschilling, L.; Truffer, B. The structuration of socio-technical regimes-Conceptual foundations from institutional theory. Res. Policy 2014, 43, 772-791. [CrossRef]

10. Geels, F.W. Ontologies, socio-technical transitions (to sustainability), and the multi-level perspective. Res. Policy 2010, 39, 495-510. [CrossRef]

11. Geels, F.W. Technological transitions as evolutionary reconfiguration processes: A multi-level perspective and a case-study. Res. Policy 2002, 31, 1257-1274. [CrossRef]

12. Smith, A.; Voß, J.-P.; Grin, J. Innovation studies and sustainability transitions: The allure of the multi-level perspective and its challenges. Res. Policy 2010, 39, 435-448. [CrossRef]

13. Hannon, M. Co-Evolution of Innovative Business Models and Sustainability Transitions: The Case of the Energy Service Company (ESCo) Model and the UK Energy System. Ph.D. Thesis, University of Leeds, Leeds, UK, 2012.

14. Svensson, O.; Nikoleris, A. Structure reconsidered: Towards new foundations of explanatory transitions theory. Res. Policy 2018, 47, 462-473. [CrossRef]

15. Frantzeskaki, N.; Loorbach, D.; Meadowcroft, J. Governing societal transitions to sustainability. Int. J. Sustain. Dev. 2012, 15, 19. [CrossRef]

16. Loorbach, D.; Wijsman, K. Business transition management: Exploring a new role for business in sustainability transitions. J. Clean. Prod. 2013, 45, 20-28. [CrossRef]

17. Schaltegger, S.; Lüdeke-Freund, F; Hansen, E.G. Business Models for Sustainability. Organ. Environ. 2016, 29, 264-289. [CrossRef]

18. Geels, F.W.; Schot, J. Typology of sociotechnical transition pathways. Res. Policy 2007, 36, 399-417. [CrossRef]

19. Apajalahti, E.-L. Large Energy Companies in Transition_From Gatekeepers to Bridge Builders; Aalto University: Helsinki, Finland, 2018.

20. Borghei, B.B. Incumbent Actors in Sectoral Transformations Towards Sustainability: A Sociotechnical Study of the European Heavy Commercial Vehicles Sector; Linköping University Electronic Press: Linköping, Sweden, 2018.

21. Dewald, U.; Achternbosch, M. Why did more sustainable cements failed so far? Disruptive innovations and their barriers in a basic industry. Environ. Innov. Soc. Transit. 2016, 19, 15-30. [CrossRef]

22. Hockerts, K.; Wüstenhagen, R. Greening Goliaths versus emerging Davids-Theorizing about the role of incumbents and new entrants in sustainable entrepreneurship. J. Bus. Ventur. 2010, 25, 481-492. [CrossRef]

23. Rodrigo, P.; Muñoz, P.; Wright, A. Transitions dynamics in context: Key factors and alternative paths in the sustainable development of nations. J. Clean. Prod. 2015, 94, 221-234. [CrossRef]

24. Chatzimentor, A.; Apostolopoulou, E.; Mazaris, A.D. A review of green infrastructure research in Europe: Challenges and opportunities. Landsc. Urban Plan. 2020, 198, 103775. [CrossRef]

25. Fischer, D. Comparing transitions: Insights from the economic transition processes in former socialist countries for sustainability transitions. Osteuropa-Wirtschaft 2010, 55, 289-310.

26. Brown, G.; Kraftl, P.; Pickerill, J.; Upton, C. Holding the Future Together: Towards a Theorisation of the Spaces and Times of Transition. Environ. Plan. A Econ. Sp. 2012, 44, 1607-1623. [CrossRef]

27. Holtz, G.; Brugnach, M.; Pahl-Wostl, C. Specifying "regime"-A framework for defining and describing regimes in transition research. Technol. Forecast. Soc. Chang. 2008, 75, 623-643. [CrossRef]

28. Sovacool, B.K.; Turnheim, B.; Martiskainen, M.; Brown, D.; Kivimaa, P. Guides or gatekeepers? Incumbent-oriented transition intermediaries in a low-carbon era. Energy Res. Soc. Sci. 2020, 66, 101490. [CrossRef]

29. Johnstone, P.; Stirling, A.; Sovacool, B. Policy mixes for incumbency: Exploring the destructive recreation of renewable energy, shale gas 'fracking,' and nuclear power in the United Kingdom. Energy Res. Soc. Sci. 2017, 33, 147-162. [CrossRef]

30. Hengelaar, G. The Proactive Incumbent: Holy Grail or Hidden Gem? Erasmus University Rotterdam: Rotterdam, The Netherlands, 2017.

31. Chandy, R.K.; Tellis, G.J. The Incumbent's Curse? Incumbency, Size, and Radical Product Innovation. J. Mark. 2000, 64, 1-17. [CrossRef]

32. Henderson, R. Underinvestment and Incompetence as Responses to Radical Innovation: Evidence from the Photolithographic Alignment Equipment Industry. RAND J. Econ. 1993, 24, 248. [CrossRef]

33. Mitchell, W. Dual clocks: Entry order influences on incumbent and newcomer market share and survival when specialized assets retain their value. Strateg. Manag. J. 1991, 12, 85-100. [CrossRef]

34. Mitchell, W.; Singh, K. Death of the Lethargic: Effects of Expansion into New Technical Subfields on Performance in a Firm's Base Business. Organ. Sci. 1993, 4, 152-180. [CrossRef]

35. Kungl, G. Stewards or sticklers for change? Incumbent energy providers and the politics of the German energy transition. Energy Res. Soc. Sci. 2015, 8, 13-23. [CrossRef] 
36. Fligstein, N.; McAdam, D. A Theory of Fields; Oxford University Press: New York, NY, USA, 2012; ISBN 0199859957.

37. Smink, M.M.; Hekkert, M.P.; Negro, S.O. Keeping sustainable innovation on a leash? Exploring incumbents' institutional strategies. Bus. Strateg. Environ. 2015, 24, 86-101. [CrossRef]

38. Turnheim, B.; Sovacool, B.K. Forever stuck in old ways? Pluralising incumbencies in sustainability transitions. Environ. Innov. Soc. Transit. 2020, 35, 180-184. [CrossRef]

39. Hörisch, J. How business actors can contribute to sustainability transitions: A case study on the ongoing animal welfare transition in the German egg industry. J. Clean. Prod. 2018, 201, 1155-1165. [CrossRef]

40. Lindberg, M.B.; Markard, J.; Andersen, A.D. Policies, actors and sustainability transition pathways: A study of the EU's energy policy mix. Res. Policy 2019, 48, 103668. [CrossRef]

41. Matschoss, K.; Heiskanen, E. Innovation intermediary challenging the energy incumbent: Enactment of local socio-technical transition pathways by destabilisation of regime rules. Technol. Anal. Strateg. Manag. 2018, 30, 1455-1469. [CrossRef]

42. Geels, F.W. Socio-technical transitions to sustainability: A review of criticisms and elaborations of the Multi-Level Perspective. Curr. Opin. Environ. Sustain. 2019, 39, 187-201. [CrossRef]

43. Geels, F.W. Regime Resistance against Low-Carbon Transitions: Introducing Politics and Power into the Multi-Level Perspective. Theory Cult. Soc. 2014, 31, 21-40. [CrossRef]

44. Walz, R.; Köhler, J. Using lead market factors to assess the potential for a sustainability transition. Environ. Innov. Soc. Transit. 2014, 10, 20-41. [CrossRef]

45. Sovacool, B.K.; Brisbois, M.-C. Elite power in low-carbon transitions: A critical and interdisciplinary review. Energy Res. Soc. Sci. 2019, 57, 10. [CrossRef]

46. Hess, D.J. Sustainability transitions: A political coalition perspective. Res. Policy 2014, 43, 278-283. [CrossRef]

47. Kallio, L.; Heiskanen, E.; Apajalahti, E.-L.; Matschoss, K. Farm power: How a new business model impacts the energy transition in Finland. Energy Res. Soc. Sci. 2020, 65, 101484. [CrossRef]

48. Wolff, S.; Brönner, M.; Held, M.; Lienkamp, M. Transforming automotive companies into sustainability leaders: A concept for managing current challenges. J. Clean. Prod. 2020, 276, 124179. [CrossRef]

49. Schumpeter, J.A. Capitalism, Socialism, and Democracy, 3rd ed.; Harper \& Brothers: New York, NY, USA, 1950.

50. Berggren, C.; Magnusson, T.; Sushandoyo, D. Transition pathways revisited: Established firms as multi-level actors in the heavy vehicle industry. Res. Policy 2015, 44, 1017-1028. [CrossRef]

51. Geels, F.W. The multi-level perspective on sustainability transitions: Responses to seven criticisms. Environ. Innov. Soc. Transit. 2011, 1, 24-40. [CrossRef]

52. Bosman, R.; Loorbach, D.; Frantzeskaki, N.; Pistorius, T. Discursive regime dynamics in the Dutch energy transition. Environ. Innov. Soc. Transit. 2014, 13, 45-59. [CrossRef]

53. Markard, J. The life cycle of technological innovation systems. Technol. Forecast. Soc. Chang. 2020, 153, 119407. [CrossRef]

54. Mossberg, J.; Söderholm, P.; Hellsmark, H.; Nordqvist, S. Crossing the biorefinery valley of death? Actor roles and networks in overcoming barriers to a sustainability transition. Environ. Innov. Soc. Transit. 2018, 27, 83-101. [CrossRef]

55. Geels, F.W. Processes and patterns in transitions and system innovations: Refining the co-evolutionary multi-level perspective. Technol. Forecast. Soc. Chang. 2005, 72, 681-696. [CrossRef]

56. Kuokkanen, A.; Nurmi, A.; Mikkilä, M.; Kuisma, M.; Kahiluoto, H.; Linnanen, L. Agency in regime destabilization through the selection environment: The Finnish food system's sustainability transition. Res. Policy 2018, 47, 1513-1522. [CrossRef]

57. Kungl, G.; Geels, F.W. Sequence and alignment of external pressures in industry destabilisation: Understanding the downfall of incumbent utilities in the German energy transition (1998-2015). Environ. Innov. Soc. Transit. 2018, 26, 78-100. [CrossRef]

58. Mignon, I.; Kanda, W. A typology of intermediary organizations and their impact on sustainability transition policies. Environ. Innov. Soc. Transit. 2018, 29, 100-113. [CrossRef]

59. Elzen, B.; van Mierlo, B.; Leeuwis, C. Anchoring of innovations: Assessing Dutch efforts to harvest energy from glasshouses. Environ. Innov. Soc. Transit. 2012, 5, 1-18. [CrossRef]

60. Haigh, N.; Hoffman, A.J. Hybrid Organizations: The Next Chapter in Sustainable Business. SSRN Electron. J. 2011, 41. [CrossRef]

61. Black, J.; Hashimzade, N.; Myles, G. A Dictionary of Economics. Incumbent Firm, 3rd ed.; Oxford University Press: New York, NY, USA, 2009; ISBN 9780199237043.

62. Cameron, D.R. Creating Market Economies after Communism: The Impact of the European Union. Post-Sov. Aff. 2009, 25, 1-38. [CrossRef]

63. Lietuvos Respublikos Vyriausybè Nutarimas Nr. 1160. Dėl Nacionalinės Darnaus Vystymosi Strategijos Patvirtinimo ir Igyvendinimo. Valstyb. Žinios. 2003. Available online: https://e-seimas.lrs.lt/portal/legalAct/lt/TAD/TAIS.217644/WPqyZkDuCy (accessed on 25 October 2021).

64. Tõnurist, P. Framework for analysing the role of state owned enterprises in innovation policy management: The case of energy technologies and Eesti Energia. Technovation 2015, 38, 1-14. [CrossRef]

65. Dawson, L. Unravelling Sustainability: The Complex Dynamics of Emergent Environmental Governance and Management Systems at Multiple Scales; Stockholm University: Stockholm, Sweden, 2019.

66. Lynn, N.J. Geography and Transition: Reconceptualizing Systemic Change in the Former Soviet Union. Slavic Rev. 1999, 58, 824-840. [CrossRef] 
67. Smith, A. From Convergence to Fragmentation: Uneven Regional Development, Industrial Restructuring, and the 'Transition to Capitalism' in Slovakia. Environ. Plan. A Econ. Sp. 1996, 28, 135-156. [CrossRef]

68. Bouzarovski, S.; Tirado Herrero, S.; Petrova, S.; Frankowski, J.; Matoušek, R.; Maltby, T. Multiple transformations: Theorizing energy vulnerability as a socio-spatial phenomenon. Geogr. Ann. Ser. B Hum. Geogr. 2017, 99, 20-41. [CrossRef]

69. Ferenčuhová, S. Not so global climate change? Representations of post-socialist cities in the academic writings on climate change and urban areas. Eurasian Geogr. Econ. 2020, 61, 686-710. [CrossRef]

70. Punytè, I.; Simonaitytè, K. Darnaus Vystymosi Tikslu Integravimas ị Kompleksinius Teritorinius Planus. Darnaus Vystymosi Tikslai ir Planavimo Sistema Lietuvoje: Esamos Situacijos Analize; Kurk Lietuvai: Vilnius, Lithuania, 2018.

71. Leal Filho, W.; Platje, J.; Gerstlberger, W.; Ciegis, R.; Kääriä, J.; Klavins, M.; Kliucininkas, L. The role of governance in realising the transition towards sustainable societies. J. Clean. Prod. 2016, 113, 755-766. [CrossRef]

72. Van der Byl, C.A.; Slawinski, N. Embracing Tensions in Corporate Sustainability: A Review of Research From Win-Wins and Trade-Offs to Paradoxes and Beyond. Organ. Environ. 2015, 28, 54-79. [CrossRef]

73. McGrail, S.; Halamish, E.; Teh-White, K.; Clark, M. Diagnosing and anticipating social issue maturation: Introducing a new diagnostic framework. Futures 2013, 46, 50-61. [CrossRef]

74. Žydžiūnaitè, V.; Sabaliauskas, S. Kokybiniai Tyrimai: Principai ir Metodai: Vadovèlis Socialiniu Mokslu Studijų Programu Studentams; Vaga: Vilnius, Lithuania, 2017.

75. Engert, S.; Baumgartner, R.J. Corporate sustainability strategy—bridging the gap between formulation and implementation. J. Clean. Prod. 2016, 113, 822-834. [CrossRef]

76. Rotter, A.; Gostincar, C. A Defense of Eastern European Science. Science 2014, 343, 839. [CrossRef]

77. Sutcliffe, L.M.E.; Batáry, P.; Kormann, U.; Báldi, A.; Dicks, L.V.; Herzon, I.; Kleijn, D.; Tryjanowski, P.; Apostolova, I.; Arlettaz, R.; et al. Harnessing the biodiversity value of Central and Eastern European farmland. Divers. Distrib. 2015, 21, 722-730. [CrossRef] 